\title{
Managing snake bite patients - our experience from a tertiary care center of North East India
}

\author{
Dr Priyam Goswami*, Dr Anupam Dutta**, Dr Prasanta Dihingia*** \\ *Assistant Professor of Medicine, **Assistant Professor of Medicine, \\ *** Associate Professor of Medicine, Assam Medical College and Hospital, Dibrugarh
}

\begin{abstract}
Introduction: Snake bite is a common problem in North East India as most of the demography includes forests, cultivated land and tea gardens which are a natural habitat to various species of snakes. Snake bite comprises a significant number of hospitalizations with fatalities in this part of the country. We studied all the cases of snake bite poisoning that came to our hospital during the monsoon seasons in the department of medicine of a tertiary care hospital.

Materials And Methods: All adult patients coming to the department of Emergency or out patients department in Assam Medical College and Hospital over a period of 1 year from July 2014 to June 2015 were include in our prospective observational study. A detailed clinical history was taken, local examination was done and all necessary laboratory examinations especially those related to bleeding and coagulation profile was done.

Results And Observations: 116 patients were included in the study which included 70 (60.3\%) male and 46 (39.7\%) female patients, the male to female ratio being 1.52:1. Out of 116, 42 (36.2\%) were poisonous snake bites and 74 (63.8\%) were non poisonous. Out of the 42 cases of poisonous snake bites, 34 (80.9\%) patients presented with hematologic symptoms, 8 (19.1\%) patients had neurological symptoms and 4 (9.5\%) patients expired during their hospital stay. Most common symptom was fright which was noted in 107 (92.2\%) patients. This was followed by local swelling (78.4\%), tingling and numbness (65.5\%) and pain at the site of bite (58.6\%). Only $9.5 \%$ patients reached tertiary care center within 4 hours of snake bite and majority (55.2\%) were delayed by more than 12 hours. The whole blood clotting time, prothrombin time and INR was significantly high in patients with hematotoxic snake bite poisoning. Polyvalent Anti Snake venom (PASV) was administered in $22(52.4 \%)$ cases out of 42 poisonous snake bite cases. 16 (47\%) cases of hematotoxic snake bite and $6(75 \%)$ cases of neurotoxic snake bite received PASV. 18 (52.9\%) cases of hematotoxic snake bite received only fresh frozen plasma (FFP), 9 (26.5\%) received FFP and PASV, 7 (20.6\%) received only PASV. Two patients developed reaction to PASV which was managed successfully with adrenalin and steroids. Neostigmine was used in all 8 cases of neurotoxic snake bite poisoning.

Conclusion: Though most of the snake bites were non poisonous, use of tourniquet and other alternative medicines caused morbidity. Hematotoxic snake bite was more common but was managed by use of polyvalent anti snake venom (PASV) and/or fresh frozen plasma. Neurotoxic snake poisoning were less common and managed by PASV and neostigmine. Two patient of hematotoxic snake bite died due to renal failure and two cases of neurotoxic snake bite died due to respiratory failure.
\end{abstract}

Keyword: Snake bite poisoning, Polyvalent Anti Snake Venom, Hematotoxic snake, Neurotoxin snake

\section{Introduction}

Snake bite is a common problem in North East India as most of the demography includes forests, cultivated land and tea gardens which are a natural habitat to various species of snakes. In India, there are 216 species, out of which 52 are poisonous ${ }^{1}$. Though most of the snakes are not poisonous but Spectacled cobra (Naja naja), common krait (Bungarus caeruleus), saw-scaled viper (Echis carinatus) and Russell's viper (Daboia russelii) are some common poisonous snakes found in India ${ }^{2}$. Hence snake bite comprises a significant number of hospitalizations with fatalities in this part of the country. Though some of the fatal cases fail to reach our tertiary care hospital, others are often delayed with local rituals and alternative medicines. We studied all the cases of snake bite poisoning that came to our hospital during the monsoon seasons in the department of medicine and analyzed them in relation to their clinical, laboratory and management outcomes.

\section{Materials And Methods}

All adult patients coming to the department of Emergency or out patients department in Assam Medical College and Hospital over a period of one (1) year from July 2014 to June 2015 were include in our prospective observational study. A detailed clinical history was taken, local examination was done and all necessary laboratory examinations especially those related to bleeding and coagulation profile was done. Necessary treatment including anti snake venom was given to the patient with full consent. 


\section{Results And Observations}

116 patients were included in the study which included 70 (60.3\%) male and $46(39.7 \%)$ female patients, the male to female ratio being 1.52:1. Out of 116, $42(36.2 \%)$ were poisonous snake bites and 74 (63.8\%) were non poisonous. Out of the 42 cases of poisonous snake bites, 34 (80.9\%) patients presented with hematologic symptoms, $8(19.1 \%)$ patients had neurological symptoms and $4(9.5 \%)$ patients expired during their hospital stay.

Table 1: Demographics of patients

\begin{tabular}{|l|l|l|l|}
\hline & Males & Females & Total \\
\hline$<20$ years & $14(12.1 \%)$ & $6(5.2 \%)$ & $20(17.2 \%)$ \\
\hline $20-29$ years & $12(10.3 \%)$ & $18(15.5 \%)$ & $30(25.9 \%)$ \\
\hline $30-39$ years & $16(13.8 \%)$ & $6(5.2 \%)$ & $22(18.9 \%)$ \\
\hline $40-49$ years & $14(12.1 \%)$ & $10(8.6 \%)$ & $24(20.7 \%)$ \\
\hline $50-59$ years & $8(6.9 \%)$ & $4(3.4 \%)$ & $12(10.3 \%)$ \\
\hline$>60$ years & $6(5.2 \%)$ & $2(1.7 \%)$ & $4(6.9 \%)$ \\
\hline Total & $70(60.3 \%)$ & $46(39.7 \%)$ & $116(100 \%)$ \\
\hline
\end{tabular}

Most common symptom was fright which was noted in 107 (92.2\%) patients. This was followed by local swelling (78.4\%), tingling and numbness $(65.5 \%)$ and pain at the site of bite $(58.6 \%)$. The fact that these symptoms were seen significantly in the patients with non poisonous snake bite (Table 2) signifies that they had nothing or very little to do with the poison per se. Tourniquet was used in $98(84.5 \%)$ patients (Table 3$)$. On further evaluation we found that there was a significant relationship between tourniquet use and these symptoms like swelling, tingling, numbness and pain at local site of snake bite $(\mathrm{p}<0.001)$. Bleeding from the bite mark was seen in $29(25 \%)$ cases and bleeding and or clotting abnormalities was documented in $34(29.3 \%)$ cases. Neurological symptoms were seen in $8(6.9 \%)$ patients. Two $(1.7 \%)$ patients were referred with renal involvement.

Table 2: Symptoms of patient during presentation

\begin{tabular}{|l|l|l|l|l|}
\hline Sl No & Symptoms and Sign & $\begin{array}{l}\text { Non poisonous snake bite } \\
\mathrm{N}=74\end{array}$ & $\begin{array}{l}\text { Poisonous snake bite } \\
\mathrm{N}=42\end{array}$ & $\begin{array}{l}\text { Total } \\
\mathrm{N}=116\end{array}$ \\
\hline 1 & Fright & $68(91.9 \%)$ & $39(92.8 \%)$ & $107(92.2 \%)$ \\
\hline 2 & Pain at the site of bite & $43(58.1 \%)$ & $25(59.5 \%)$ & $68(58.6 \%)$ \\
\hline 3 & Local swelling & $57(77 \%)$ & $34(80.9 \%)$ & $91(78.4 \%)$ \\
\hline 4 & Tingling numbness & $39(52.7 \%)$ & $37(88.1 \%)$ & $76(65.5 \%)$ \\
\hline 5 & Bleeding from site of bite & $2(2.7 \%)$ & $29(69 \%)$ & $31(26.7 \%)$ \\
\hline 6 & Prolonged clotting time & 0 & $34(80.9 \%)$ & $34(29.3 \%)$ \\
\hline 7 & Drooping of eyelids & 0 & $8(19 \%)$ & $8(6.9 \%)$ \\
\hline 8 & Difficulty in speech/swallowing & 0 & $6(14.3 \%)$ & $6(5.2 \%)$ \\
\hline 9 & Difficulty in breathing & 0 & $6(14.3 \%)$ & $6(5.2 \%)$ \\
\hline 10 & Reduced micturation & 0 & $2(4.8 \%)$ & $2(1.7 \%)$ \\
\hline
\end{tabular}

Only $9.5 \%$ patients reached tertiary care center within 4 hours of snake bite and majority (55.2\%) were delayed by more than 12 hours (Table 3). Delay was due to various reasons like availability of vehicle for transport, ignorance and illiteracy mostly among rural farmers and tea garden workers. A significant number of patients (30.2\%) first indulged in alternative medicines and local rituals. 31.9\% used lime, turmeric and other unknown herbal pastes in the local site. All these have significant impact on the morbidly on not only the poisonous snake bite cases but also in non-poisonous snake bite cases also.

Table 3: Profile and duration/delay of first aid done in periphery

\begin{tabular}{|c|c|c|c|c|}
\hline S1 no & $\begin{array}{l}\text { Interventions done before } \\
\text { coming to tertiary care hospital }\end{array}$ & $\begin{array}{l}\text { Non poisonous snake bite } \\
\mathrm{N}=74\end{array}$ & $\begin{array}{l}\text { Poisonous snake bite } \\
\mathrm{N}=42\end{array}$ & $\begin{array}{l}\text { Total Snake bite } \\
\mathrm{N}=116\end{array}$ \\
\hline 1 & Tourniquet & $59(79.2 \%)$ & $39(92.8 \%)$ & $98(84.5 \%)$ \\
\hline 2 & Lime/Turmeric/unknown paste & $23(31.1 \%)$ & $14(33.3 \%)$ & $37(31.9 \%)$ \\
\hline 3 & Tetanus toxoid injection & $12(16.2)$ & $7(16.7 \%)$ & $19(16.4 \%)$ \\
\hline 4 & Alternative medicine/Rituals & $19(25.7 \%)$ & $16(38.1 \%)$ & $35(30.2 \%)$ \\
\hline \multicolumn{5}{|c|}{ Time interval between snake bite and hospitalization to tertiary care center } \\
\hline a) & Less than 4 hours & $6(8.1 \%)$ & $5(11.9 \%)$ & $11(9.5 \%)$ \\
\hline b) & 4 hours to 12 hours & $27(36.5 \%)$ & $14(33.3 \%)$ & $41(35.3 \%)$ \\
\hline c) & More than 12 hours & $41(55.4 \%)$ & $23(54.8 \%)$ & $64(55.2 \%)$ \\
\hline
\end{tabular}

The whole blood clotting time, prothrombin time and INR was significantly high in patients with hematotoxic snake bite poisoning (Table 4). Rests of the parameters were comparable in all the groups. Two 
patients with hematotoxic snake bite had presented with renal failure and expired. Two patients with neurotoxic snake bite also died following respiratory failure.

Table 4 : Laboratory parameters of patients

\begin{tabular}{|l|l|l|l|}
\hline Sl no & $\begin{array}{l}\text { Non poisonous snake } \\
\text { bite }(\mathrm{N}=74)\end{array}$ & $\begin{array}{l}\text { Hematotoxic snake bite } \\
(\mathrm{N}=34)\end{array}$ & $\begin{array}{l}\text { Neurotoxic snake bite } \\
(\mathrm{N}=8)\end{array}$ \\
\hline Whole blood clotting time & $8.4 \pm 1.7 \mathrm{~min}$ & $28.6 \pm 2.9 \mathrm{~min}$ & $7.2 \pm 0.8 \mathrm{~min}$ \\
\hline Prothrombin Time & $11.8 \pm 2.9 \mathrm{sec}$ & $69.3 \pm 3.1 \mathrm{sec}$ & $10.9 \pm 1.6 \mathrm{sec}$ \\
\hline INR & $0.93 \pm 0.16 \mathrm{sec}$ & $8.71 \pm 4.13 \mathrm{sec}$ & $0.87 \pm 0.11 \mathrm{sec}$ \\
\hline Hemoglobin & $10.4 \pm 2.3 \mathrm{gm} \%$ & $9.6 \pm 1.6 \mathrm{gm} \%$ & $10.5 \pm 2.7 \mathrm{gm} \%$ \\
\hline Total leukocyte count & $8.6 \pm 0.4 \times 10^{3} / \mathrm{cmm}$ & $9.3 \pm 0.8 \times 10^{3} / \mathrm{cmm}$ & $8.9 \pm 0.2 \mathrm{X} 10^{3} / \mathrm{cmm}$ \\
\hline Blood urea & $18.6 \pm 4.4 \mathrm{mg} \%$ & $32.51 \pm 6.2 \mathrm{mg} \%$ & $23.4 \pm 2.1 \mathrm{mg} \%$ \\
\hline Serum creatinine & $0.92 \pm 0.32 \mathrm{mg} \%$ & $1.36 \pm 1.13 \mathrm{mg} \%$ & $0.83 \pm 0.07 \mathrm{mg} \%$ \\
\hline
\end{tabular}

Polyvalent Anti Snake venom (PASV) was administered in 22 (52.4\%) cases out of 42 poisonous snake bite cases. $16(47 \%)$ cases of hematotoxic snake bite and $6(75 \%)$ cases of neurotoxic snake bite received PASV. 18 (52.9\%) cases of hematotoxic snake bite received only fresh frozen plasma (FFP), $9(26.5 \%)$ received FFP and PASV, 7 (20.6\%) received only PASV (Image 1). FFP was used in a total of $28(82.4 \%)$ cases of hematotoxic snake bite poisoning with very good results. Two patients developed reaction to PASV which was managed successfully with adrenalin and steroids. Neostigmine was used in all 8 cases of neurotoxic snake bite poisoning. Antibiotics, hydration, tetanus toxoid were given to all patients. A minimum of 24 hours of hospitalization for observation and routine blood examination was advocated in nonpoisonous snake bite poisoning cases. Local care of bite wound, tourniquet injury and local chemical burn due to alternative medicine use was also taken care of.

Image 1 : Use of Polyvalent Anti Snake Venom (PASV) and other treatment modalities

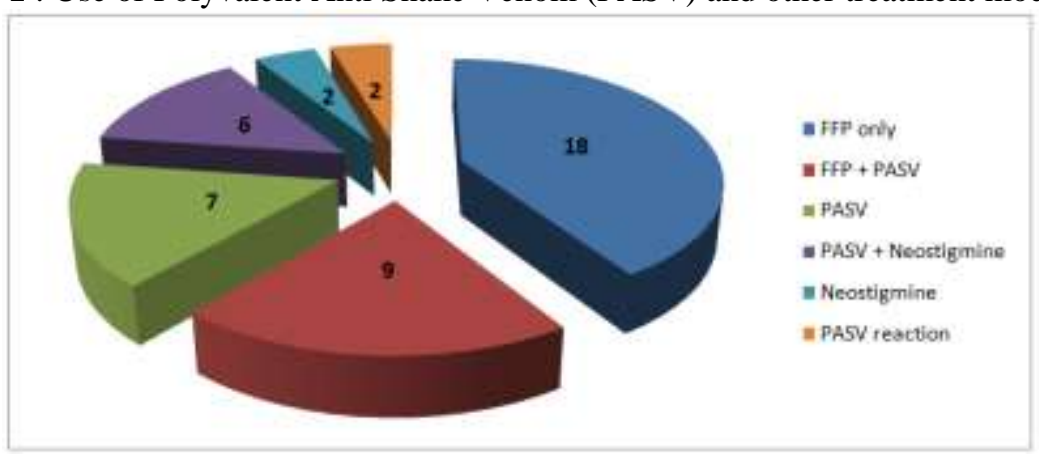

\section{Discussion}

Various studies from India has shown different demographics and profile of snake bite. Anjum A et al ${ }^{3}$ from North India studied 169 snake bite patients, consisting of $116(68.7 \%)$ male and $53(31.3 \%)$ female, of whom $85.2 \%$ (144) had fright, $57.9 \%$ (98) pain at the local site . Bawaskar HS et al ${ }^{4}$ from Western India studied 182 cases, of whom 53 (96\%) had local edema with fangs marks, 40 (72\%) had active bleeding from vein puncture site and abrasion over other part of body. While 19(34\%) had active bleeding from gums, and hematuria. Redewad $\mathrm{N}$ et al $^{5}$ from Central India studied 203 patient of snake bite from June 2011 to September 2013 and found cellulitis $(90.6 \%)$ being most common presentation. We found $70(60.3 \%)$ male and $46(39.7 \%)$ female patients, of whom $42(36.2 \%)$ were poisonous snake bites and $74(63.8 \%)$ were non poisonous. Out of the 42 cases of poisonous snake bites, 34 (80.9\%) patients presented with hematologic symptoms, $8(19.1 \%)$ patients had neurological symptoms and $4(9.5 \%)$ patients expired during their hospital stay.

Chaudhari TS et $\mathrm{al}^{6}$ from central India found that out of 260 patients, 186 (71.5\%) patients were from rural areas and $63.4 \%$ of bites occurred during rainy season. Anjum A et al ${ }^{3}$ also found $82(48.5 \%)$ was involved in agriculture. They noted that most of snake bite cases were from rural region i.e. $114(67.5 \%)$ and mostly the bites occurred outdoors i.e. $106(62.7 \%)$. Bawaskar HS et al ${ }^{4}$ also noted that $125(68 \%)$ are between age 21-40 years are actively involved in farming. We also found that most of our patients were from rural background and all noted in the monsoon season.

Chaudhari TS et $\mathrm{al}^{6}$ found 260 patients $(100 \%)$ had pain at site of bite, local swelling in $252(96.9 \%)$ and blackening of skin, blebs in 18 (6.9\%). Seventy-seven (29.6\%) had bleeding tendencies. Ptosis was present in all the 65 patients with signs of neuroparalysis. Eighty (30.8\%) patients had acute renal failure. Redewad N et $\mathrm{al}^{5}$ found nausea and vomiting $(70.4 \%)$, ptosis $(19.2 \%)$, colour changes in form of bluish discoloration of bite site $(12.8 \%)$, respiratory failure and haematuria (7.4\%) and hypotension (6.9\%). $30(14.8 \%)$ patient died during the study. We also found 31 (26.7\%) patients with bleeding from site of bite, 34 (29.3\%) with prolonged clotting 
time, 8 (6.9\%) with drooping of eyelids, $6(5.2 \%)$ with difficulty in speech/swallowing, $6(5.2 \%)$ with difficulty in breathing.

Redewad N et al ${ }^{5}$ found that out of 203 cases studied 30, patients were died during the study period and overall mortality was $14.8 \%$. Chaudhari TS et $\mathrm{al}^{6}$ found that out of 260 patients, 58 died and 202 survived. Bawaskar HS et $\mathrm{al}^{4}$ found 44 (91\%) cases had neuroparalysis, $26(54 \%)$ cases had respiratory depression, were intubated and given artificial respiration ( 23 on ventilator, 3 on ambu bag) of these 7 died (4 died before hospitalization). Anjum A et $\mathrm{al}^{3}$ noted that $7.7 \%$ expired, among them the major cause of death was respiratory failure. We found much lower mortality of $9.5 \%$ ( 4 cases) out of 42 poisonous snakes. This may be because most of the lethal cases fail to reach our tertiary care center.

Redewad $\mathrm{N}$ et al ${ }^{5}$ saw noted that the risk of mortality was 3.35 times higher among the patient who had developed acute renal failure than those who didn't have acute renal failure. (P value -0.032,S). Two of our patient who had renal failure also died.

Anjum A et $\mathrm{al}^{3}$ noted that $81.1 \%$ were administered anti-snake venom (ASV) and most of them $74.6 \%$ recovered without sequelae. Redewad $\mathrm{N}$ et al ${ }^{5}$ saw that out of 203 cases of snake bite, 188 (92.6\%) patient received ASV treatment. They had statistically significant less mortality $(9.6 \%)$ as compared to 15 patients (7.4\%) who didn't received ASV treatment $(80 \%)$. Bawaskar HS et al ${ }^{4}$ noted that three patients were sensitive to ASV. ASV was administered with in an intravenous drip preceded intramuscular adrenaline. $52.4 \%$ of our cases received ASV. Bawaskar HS et $\mathrm{al}^{4}$ also noted that ASV is a costly medicine and is difficult for poor farmers and rural villagers to afford the whole treatment dose. We also found that many of our poor patients could not afford ASV. So we used fresh frozen plasma instead. We observed that 18 (52.9\%) cases of hematotoxic snake bite received only fresh frozen plasma (FFP) and $9(26.5 \%)$ received FFP and PASV. We conclude that FFP is an effective alternative in patients who could not afford PASV.

\section{Conclusion}

We conclude that though most of the snake bites are non poisonous, tourniquet use, alternative medicine use, various rituals and delay in attending medical care centers increases the morbidity in all cases. Most of the poisonous snake bite were hematotoxic and responded well to PASV. In patients who could not afford PASV, FFP was used with very good results. . Neurotoxic snake poisoning were less common and managed by PASV and neostigmine. Two patient of hematotoxic snake bite died due to renal failure and two cases of neurotoxic snake bite died due to respiratory failure.

\section{Reference}

[1]. Bhattacharya P, Chakraborty A; Neurotoxic snake bite with respiratory failure. Indian J Crit Care Med., 2007; 11:161-164

[2]. Mohapatra B, Warrell DA, Suraweera W, Bhatia P, Dhingra N, Jotkar RM et al.; Snakebite Mortality in India: A Nationally Representative Mortality Survey. PLOSNegl Trop Dis 2011; 5(4): e1018.

[3]. Anjum A, Husain M, Hanif SA, Ali SM, Beg M, et al. (2012) Epidemiological Profile of Snake Bite at Tertiary Care Hospital, North India. J Forensic Res 3:146. doi:10.4172/2157-7145.1000146

[4]. Bawaskar HS, Bawaskar PH, Punde DP, Inamdar MK, RB Dongare, Bhoite RR. Profile of Snakebite Envenoming in Rural Maharashtra, India. JAPI, FEBRUARY 2008 ,VOL. $56,88-95$

[5]. Nagnath R, Bhaisare SD, Bansod YV, Management and Outcome Study of Snake Bite Cases in Central India Hire R, Sch. J. App. Med. Sci., 2014; 2(1D):435-441

[6]. Chaudhari TS, Patil TB, Paithankar MM, Gulhane RV, Patil MB. Predictors of mortality in patients of poisonous snake bite: Experience from a tertiary care hospital in Central India. Int J Crit Illn Inj Sci. 2014 Apr-Jun; 4(2): 101-107. 